\title{
Western Red Cedar (Thuja plicata Donn) in Nova Scotia
}

\author{
by
}

D. P. Fowler ${ }^{1}$

For many years Dr. W. H. Brittain, former Dean of Agriculture (1934-1955) and curator of the Morgan Arboretum (1958-1963) at Macdonald College, maintained a small log camp as a summer hideaway on Zwicker ${ }^{2}$ Lake, Hants County, Nova Scotia. Over the years, starting sometime in the 1930's, he planted several non-native tree species in the vicinity of this camp. I first met Dr. Brittain while I was working as a student assistant to Dr. Carl Heimburger at the Southern Research Station, Maple, Ontario. $\mathrm{He}$ had several of Heimburger's pine hybrids growing in the Morgan Arboretum and these provided a valid excuse to stop and visit whenever we passed through Macdonald College. After completing graduate studies, I joined Dr. Heimburger at Maple and was able to continue my association with Dr. Brittain.

In August 1957, on route to the Maritimes to examine red pine growing on poorly drained sites near Stanley, N.S. (I was working on the genetics of red pine at that time), I stopped to see Dr. Brittain. On hearing where I was going, he urged me to visit his camp and see the trees he had established there.

After completing the fieldwork near Stanley, and following Dr. Brittain's directions, I drove to Upper Vaughan, located Mr. Wallace H. Smeltzer, borrowed his canoe and paddled down the lake. I had no difficulty locating the cabin as it was surrounded (landscaped if you prefer) with trees of several species quite out-of-place in Nova Scotia. Dr. Brittain had planted Douglas fir, Sitka spruce, lodgepole pine, Scots pine, western red cedar, eastern red cedar and some hardwoods including western white birch. There were only a few trees of each species and, although planted in a most natural setting, they could be easily distinguished from the native vegetation.

I spent several hours wandering around the property attempting to sort out, to my own satisfaction, just what had been planted. Most of the non-native species, although interesting, were not growing any better than the natives. The one exception was western red cedar. There were six or more of these planted between the surface boulders from 10 to $50 \mathrm{~m}$ back from the lake shore. The tallest was about $10 \mathrm{~m}$ and $14 \mathrm{~cm}$ in diameter (breast height). They all appeared healthy, quite at home in their new environment, and some of them had begun producing cones. I collected cuttings

\begin{tabular}{|c|c|c|c|c|}
\hline \multirow[b]{2}{*}{$\begin{array}{c}\text { Tree } \\
\text { number }\end{array}$} & \multicolumn{2}{|c|}{1957} & \multicolumn{2}{|c|}{1980} \\
\hline & $\begin{array}{c}\text { Height } \\
\text { m }\end{array}$ & $\begin{array}{l}\text { Dbh } \\
\mathrm{cm}\end{array}$ & $\begin{array}{l}\text { Height } \\
\text { m }\end{array}$ & $\begin{array}{l}\text { Dbh } \\
\text { cm }\end{array}$ \\
\hline 1 & 10 & 14 & 19.5 & 54.1 \\
\hline 2 & 7 & 8 & 18.0 & 42.0 \\
\hline 3 & 9 & 9 & 19.0 & 29.6 \\
\hline 4 & 9 & 9 & 19.0 & 29.9 \\
\hline 5 & - & - & 16.0 & 28.6 \\
\hline 6 & - & - & 17.3 & 34.7 \\
\hline
\end{tabular}
${ }_{1}^{1}$ Maritimes Forest Research Centre, Canadian Forestry Service, Fredericton, N.B. E3B
5P7.

2 Zwicker Lake appears as Daniel Lake on "Maps of Nova Scotia (1954) produced by NS Dept. Mines and published by NS Communication and Information Centre. The lake is known locally as Zwicker Lake and is shown as such on other maps.

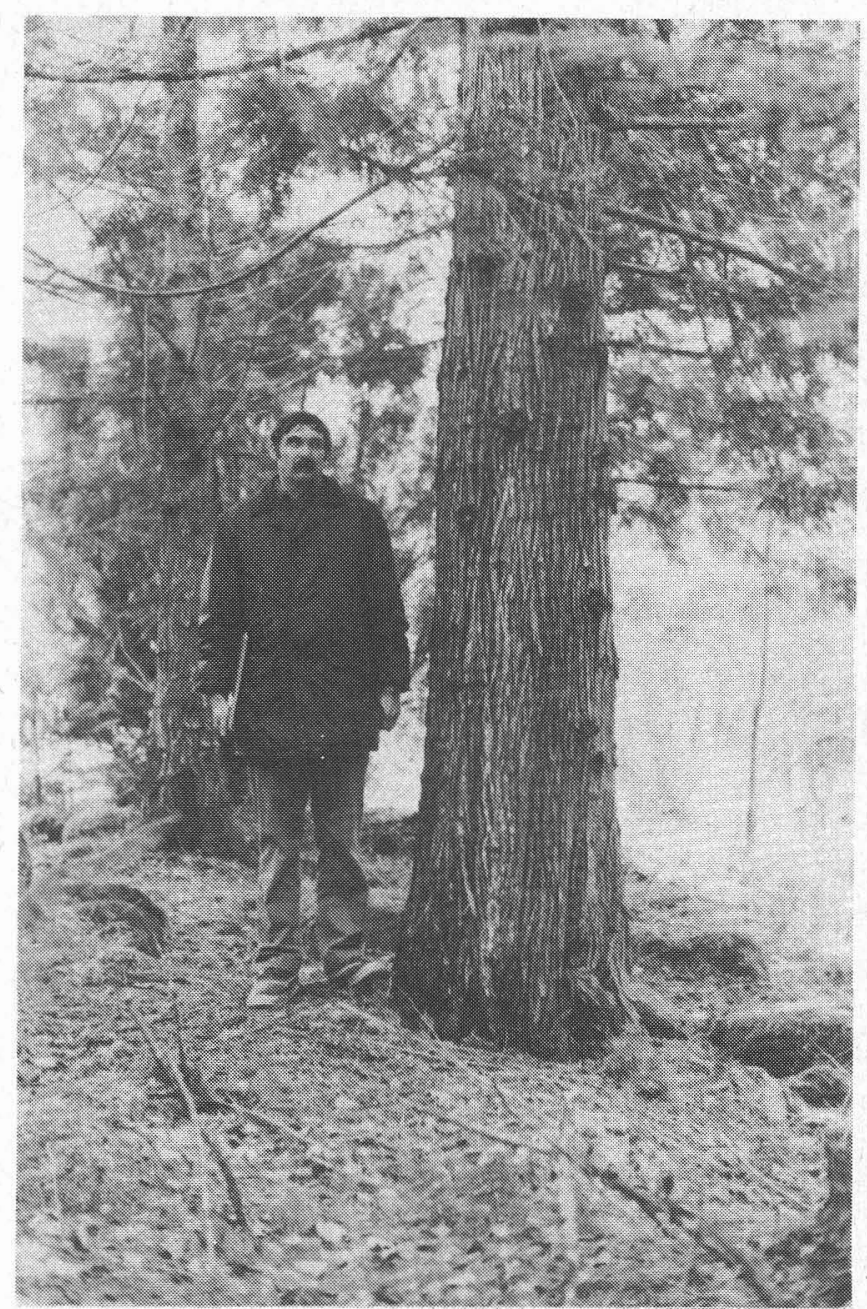

Western red cedar, growing in Hants County, Nova Scotia. Age 45 $\mathrm{yr}$, height $19.5 \mathrm{~m}$, dbh $54 \mathrm{~cm}$.

and made rough notes on the location and sizes of the four best cedars.

On my return to Maple, I struck the cuttings in a rooting bed. Some cuttings from each of the four trees rooted (18-84\% rooting). These were transplanted into the nursery and eventually into a small field planting at Maple. The resulting trees were obviously not at home in their Ontario environment, but they did survive.

For the next 20 years I almost forgot about Dr. Brittain's western red cedars. In June 1980, while driving through Nova Scotia I remembered and decided to relocate them. I found Zwicker Lake and followed a new road along the west side of the lake. Cottages now adorn the shoreline, but there at the end of the road was Dr. Brittain's old log camp much the same as it had been 23 years earlier. The area around the camp and adjoining property had been cleaned and many of Dr. Brittain's trees bore identification tags. He would have been pleased to see the care that had gone into up-keep of the property. 
I subsequently learned that the new owner was $G$. G. Smeltzer, a long-time friend of Dr. Brittain and son of the man from whom I had borrowed the canoe in 1957. Mr. Smeltzer kindly allowed me to remeasure the cedars, which I did in September.

From my 1957 notes, I was able to relocate the four trees from which I had taken cuttings and measurements. I remeasured these same four trees plus two additional trees which I evidently had not considered worthy in 1957 . The 1957 and 1980 data are presented in the Table. The photograph is of the largest tree. The trees are approximately 45 years old (determined by increment borings at stump height), have attained a height of 16-19.5 $\mathrm{m}$ (mean 18.4) and are continuing to grow well. The largest tree is $54 \mathrm{~cm}$ in diameter at breast height.

The western red cedars are regenerating naturally. There are about 25 trees between 1 and $12 \mathrm{~m}$ in height and probably several hundred small seedlings, all within a distance of $100 \mathrm{~m}$ of Dr. Brittain's camp. All six of the original trees had a bountiful cone crop in 1979 .

An obvious question at this point is: does western red cedar have any real potential in Nova Scotia? Northern white cedar (Thuja occidentalis L.), a close relative of western red cedar, although almost ubiquitous over much of mainland eastern Canada and New England, is conspicuous by its absence in most parts of Nova Scotia. In Nova Scotia, native cedar is a scarce tree confined to a few isolated locations in Digby and Yarmouth counties. It has been widely planted as an ornamental and has "escaped" in parts of the
Annapolis Valley.

The wood of western red cedar, which is much the same as that of northern white cedar, is lignt, easily worked, decay resistant and yet comparatively strong. It is particularly valuable for use in situations favourable to decay, such as shingles, posts, boats, greenhouses and exterior siding. Cedars are also favoured as ornamentals.

The success of Dr. Brittain's small trial suggests that the species could be a valuable addition to the Nova Scotia flora. Unfortunately there is no information on their origin. It is possible that the seeds came from a single tree although the fact that the trees are regenerating well and the seedlings are healthy and vigorous suggests the original trees are unrelated, i.e., there is no evidence of inbreeding depression.

The lack of information on seed origin, precludes the direct importation of seed for use in Nova Scotia or elsewhere in the Maritimes. It will be necessary to establish seed source trials to determine where we should collect seeds for use in various parts of the Region. It will also be necessary to determine which sites and environments are best suited for the species. As an interim step before seed source information is available, cones could be collected from the trees near Dr. Brittain's camp. These could be sown in a greenhouse or nursery and the best seedlings (those with good growth and no evidence of winter damage) selected and propagated vegetatively by rooting cuttings. These could be used on a modest scale for reforestation.

\section{Woodlot Service (1978) Ltd.}

"All Matters Pertaining to Forestry"

GORDON B. YOUNG, B.Sc.F., M.F.

Registered Professional Forester

320 Maple Street

Bus.: 506 - $472-3396$

Fredericton, N.B.

\section{$\mathbf{k b m}$ FORESTRY CONSULTANTS INC.}

360 MOONEY STREET

THUNDER BAY, ONTARIO

P7B $5 R 4$

TEL.: 344-0811

\author{
RESOURCE INVENTORY - \\ FOREST MANAGEMENT PLANNING \\ SILVICULTURAL SPECIALISTS \\ SYSTEM DESIGN AND CONTRACT
}

